\title{
A Study on the Contributions of PACS towards Inclusive Growth of Rural Economy
}

\author{
Sonali Senapati, Asha Bhatia \\ K. J. Somaiya Institute of Management Studies \& Research, Mumbai, India \\ Email:ashabhatia@somaiya.edu
}

How to cite this paper: Senapati, S. and Bhatia, A. (2018) A Study on the Contributions of PACS towards Inclusive Growth of Rural Economy. Theoretical Economics Letters, 8, 2818-2829. https://doi.org/10.4236/tel.2018.813177

Received: September 6, 2018

Accepted: October 9, 2018

Published: October 12, 2018

Copyright $\odot 2018$ by authors and Scientific Research Publishing Inc. This work is licensed under the Creative Commons Attribution International License (CC BY 4.0).

http://creativecommons.org/licenses/by/4.0/

(c) (i) Open Access

\begin{abstract}
Credit cooperatives are regarded as an important source of agricultural credit for the vast majority of farmers in rural India. Institutions of Cooperative Credit had their launching in India after the enactment of Cooperative Societies Act of 1904 with the objective of emancipating the farmers from the clutches of money lenders. After independence a lot of efforts have been made by the Government of India and the State Governments to make the credit cooperatives efficient and farmer friendly. Indian economy is primarily agrarian in nature with more than $70 \%$ of the people living in rural areas. Agriculture happens to be the mainstay of livelihood for about $50 \%$ of the population of the country. Over the years cooperative credit has made phenomenal expansion in terms of membership coverage, credit advance etc. Primary Agricultural Cooperative Society (PACS) operates at the village level to cater to the credit needs of the farmers in rural areas. It may be observed that, the PACS is the foundation on which the entire cooperative structure is built upon. However many PACS suffer from small size, infrastructural weakness, operational inefficiency and structural flaws. In this context a number of Committees have been formed since 1945 starting from Cooperative Planning Committee to the latest, the Vaidyanathan Committee where recommendations were made to strengthen the cooperatives in the country. On the above backdrop the present article attempts to study the growth of cooperative credit particularly Primary Agricultural Credit Society (PACS) in terms of number of societies, membership, deposits, number of borrowers, loan advanced in India. It also focuses on the measures taken by different committees to revamp and revitalize the PACS. The study is primarily based on secondary data collected from the National federation of State Cooperative Banks Ltd. (NAFSCOB) and other published sources.
\end{abstract}

\section{Keywords}

Primary Agriculture Credit Society (PACS), Rural Economy, Institutional 
Credit, CAGR

\section{Introduction}

Primary agricultural credit society (PACS) forms the base of the cooperative credit structure in India. India is primarily an agrarian economy where around 70 percent of the population lives in rural areas and 55 percent of the population depends on agriculture. Agricultural activities constitute the mainstay of the rural population in India. Adequate and timely availability of institutional credit plays a pivotal role in agricultural development, particularly in enhancing its productivity and improving the living standard of the peasant communities. It accelerates the pace of agricultural development if it is adequate in quantity, cheap, and timely made available [1] [2] [3]. Credit is not only a critical input in agriculture but it is also an effective means of economic transformation of rural areas. Growing commercialization, diversification and capitalization of agriculture through the use of modern technologies, largely driven by the forces of globalization, ipso facto, have increasingly raised the credit needs of the peasants [4]. The rural cooperative credit structure comprises of short term and long term cooperative credit structures. The short term credit structures is organised as a three tier system with State Cooperative bank at the apex, district central cooperative banks (DCCBS) in the middle and Primary Agricultural credit societies (PACS) at the base. PACS is organised at the village level that accepts deposits from rural farmers and gives loans for agricultural purpose. PACS is considered as vital agencies to resolve a host of problems in agricultural development and uplift the socio-economic status of the poor and weaker sections of the society [5].

Over the years, institutional credit has undergone a sea change. Since the inception of the cooperative movement in 1904 and more particularly in the post-independence era, a lot of reforms and restructuring have been carried out in the cooperative organization. To meet the rising demand for credit under the impact of technological changes, PACS has substantially widened their network of membership credit and non-credit business. At the end of March 2017, there are 95,955 PACS with a total membership of 151,857 mobilising Rs $11,588,420$ as deposits and advancing loans amounting to Rs 20,067,839. More than half of members of PACS are persons of small means-small farmers, agricultural labourers, rural artisans, and $25 \%$ of them belong to SC/ST.

Yet, over time a number of problems have cropped up which have threatened their existence and continuance as an institutional credit agency. In terms of participation, productivity and repayment rates failures have outnumbered the success. Besides, it is often alleged that cooperative credit distribution has remained uneven across regions and farm categories [6]. The Khusro Committee has also highlighted that the credit distribution of PACS was iniquitous between the states [7]. Studies undertaken by the individual researchers have also cor- 
roborated the findings obtained at the macro level. The large scale of non-repayment of loans and mounting of dues has also been reported by a number of studies [8].

Barring aside the glaring disparities in the distribution of cooperative credit, the PACS suffers from many ailments such as lack of spontaneity, weak financial system, defective management and leadership, too much government interference etc. The Report of the Task Force on Revival of Rural Cooperative Credit Institutions has amply elaborated on the various ailments of PACS. The report stated that the cooperative credit structure is today impaired in governance, managerial and financial fronts. There is non-conduct of elections for a long time, frequent supersession of Boards, delay in audit and state's intrusion in administrative and financial. The study revealed that in the post-reform era, the institutional credit delivery system is undergoing structural transformation and thus creating a competitive environment for the financial institutions especially the cooperatives. The study found out that the continuous deterioration in the financial health of the cooperatives is largely due to internal and external factors. Internal factors mainly relate to poor resources base, lack of professionalism in management etc. Some of the external factors relate to State Government control with high degree bureaucratization, multiplicity of control over these institutions, PDS operators etc. It has suggested measures to strengthen and improve the performance of cooperative credit institutions.

\section{Review of Literature}

Bhuyan, U. [9] has stated that certain factors such as Gross domestic factor, interest rates on lending by banks, financial performance of banks (NPAs of banks, asset quality, capital adequacy ratio etc.), commodities prices and consumption propensity play a very important role in bank credit.

Vijaykumar J. [10] in his article has analysed the monetary performance of primary agriculture cooperative societies and their contribution to the financial inclusion of farmers and the agricultural development of India.

Shah D. [11] in his study states that during the period between 1991 and 2000, Financial Institutes in Maharashtra have shown a slower growth in their loan advances and other operational indicators and a poor performance after that. This has resulted in a number of cotton growing farmers committing suicide from the Vidarbha region as loan advances are not available to them and if made available, financial institutes are creating pressure to recover loan despite crop failure.

Kumar, V., Wankhede et al. [12] mentioned that members of cooperatives through the use of suitable farming systems, can generate year round employment and sustainable income by growing crops, vegetables, fruits and livestock. However they need additional support to make the model sustainable.

Kannusany \& Nirmala [13] have made a study on the growth of pattern of primary agricultural credit societies in India. The study explains the vital role 
played by PACS in the development of agriculture. The study reveals that the membership pattern during 2001-2010 has increased with an average compound growth rate of $3.92 \%$. In terms of financial indicators, the share capital of PACS has increased during the study period. Along with that the Government holdings have also increased. PACS has also shown good performance in providing loans.

Choudhuri, Shinde and Mahod [14] studied the crop loans provided by PACS and its utilization by the farmers. It also made a study on the repayment of crop loan by the cotton growers. The success of cooperatives with regard to recovery of crop loan largely depends on the productive utilization of agricultural credit by the borrowers. The study showed that the recovery of crop loan by PACS was low because the loan taken for cultivation of cotton crop was not utilized productively. Hence, there is a need to monitor the utilization of crop loan by cotton growers.

Sudarsan Nayak [15] conducted a study on cooperative credit in Odisha. His study revealed that cooperative credit societies constitute an integral part of state agricultural development programme as it renders $70 \%$ of total agricultural credit requirement of the state. The cooperatives are considered as an effective mechanism of structural change. It needs to be strengthened with high degree of professionalization, strive for an objective orientation.

The above studies focus on the importance of PACS in the development of agriculture. The studies have also identified a gap where it is difficult for small farmers to get loan advances and then there is undue pressure from financial institutes to repay the loan.

\section{Objectives}

On the above backdrop, the objectives of our study are as follows:

1) To study the growth of PACS in terms of number of societies, membership, number of borrowers, deposits and loans advanced that will give an insight into the spread and level of involvement of PACS in the rural areas.

2) To study the recommendations made by various committees over the years as the PACS suffers many weaknesses and needs to be revamped in the wake of increased competition from other financial institutions.

\section{Significance}

As mentioned above, India is predominantly an agrarian economy as more than 50 percent of the population depends on agriculture. PACS caters to the short term credit needs of the small and marginal farmers. The timely availability of loans will support the rural farmers to enhance the productivity in agriculture and that would lead to an overall growth of the economy. This research gives an insight to the outreach of PACS through short term credit disbursement to the rural farmers in India over the decade. 


\section{Methodology}

The present study is based on secondary data collected from the websites of NAFSCOB, RBI and other published sources, books and journals. The study attempts to study the growth of PACS in terms of number of societies, membership, number of borrowers, deposits and loans advanced, for this purpose a compound annual growth rate (CAGR) is calculated by taking the data for a period of 10 years from 2007-2008 to 2016-2017.

$$
\mathrm{CAGR}=[(\text { End value } / \text { Beginning value }) \wedge(1 / \text { years })]
$$

The recommendations made by different committees to revamp the PACS were studied from various government publications and reports that have been published from time to time.

\section{Analysis}

The current study has been conducted and data analysed in two sections. Section A deals with calculation of Compound Annual growth rate (CAGR) to study the growth of PACS in terms of number of societies, membership, number of borrowers, deposits and loans advanced.

Section B deals with the study of recommendations made by different committees to revamp and revitalize the PACS.

\subsection{Section A}

Study the growth of PACS in terms of number of societies, membership, number of borrowers, deposits and loans advanced.

The data relating to the number of societies, membership, number of borrowers, deposits and loans advanced is given in Table 1 and Table 2 .

The above table shows that the number of societies, membership and total number of borrowers in 2007-2008 was 94,950, 131,530 and 51,074 respectively. It has steadily increased over the years. At the end of March 2017 the number of societies, membership and total number of borrowers is 95,595, 151,857 and 70,234 . The CAGR for the number of societies, total memberships and the total number of borrowers stands at $0.77 \%, 1.44 \%$ and $3.25 \%$ respectively.

Figure 1 shows that there has been a fluctuating growth in the number of societies.

In Figure 2 the total number of members shows a steady growth of $15.45 \%$ over time.

In Figure 3 the total number of borrowers has increased over 10 years by 19160. The total number of borrowers has decreased drastically from year $2009-2010$ to $2011-2012$ by $24.93 \%$. This is due to decrease in number of societies and members. But in the 10 years span, total number of borrowers has increased by $27.28 \%$ with respect loan amount taken by borrowers is increased by $13.28 \%$.

In Table 2 the total number of borrowers has increased by 19160 over 10 years. 
Table 1. All India position of PACS in terms of number of societies, total memberships and number of borrowers from 2007-2008 to 2016-2017 in 000, (\%).

\begin{tabular}{cccc}
\hline Year & Number of societies & Total membership & Total number of borrowers \\
\hline $2007-2008$ & 94,950 & 131,530 & 51,074 \\
$2008-2009$ & 95,633 & 132,350 & 46,219 \\
$2009-2010$ & 94,647 & 126,419 & 59,800 \\
$2010-2011$ & 93,413 & 121,225 & 52,388 \\
$2011-2012$ & 92,432 & 113,596 & 44,886 \\
$2012-2013$ & 93,488 & 127,468 & 49,533 \\
$2013-2014$ & 93,042 & 130,120 & 48,081 \\
$2014-2015$ & 92,789 & 121,088 & 49,858 \\
$2015-2016$ & 93,367 & 127,322 & 46,214 \\
$2016-2017$ & 95,595 & 151,857 & 70,234 \\
CAGR & 0.77 & 1.44 & 3.23 \\
\hline
\end{tabular}

Source: NAFSCOB.

Table 2. All India position of PACS in term of total deposits and loan advanced from 2007-2008 to 2016-2017 Amount in Lakhs, (\%).

\begin{tabular}{ccc}
\hline Year & Total deposits & short term loans advanced \\
\hline $2007-2008$ & $2,544,926$ & $5,764,248$ \\
$2008-2009$ & $2,624,538$ & $5,878,674$ \\
$2009-2010$ & $3,528,607$ & $7,493,754$ \\
$2010-2011$ & 372,381 & $9,130,382$ \\
$2011-2012$ & $5,025,279$ & $10,730,023$ \\
$2012-2013$ & $6,711,309.77$ & $16,190,916$ \\
$2013-2014$ & $8,189,490.64$ & $17,141,956$ \\
$2014-2015$ & $8,461,632.91$ & $15,905,029$ \\
$2015-2016$ & $10,106,547.89$ & $18,082,350$ \\
$2016-2017$ & $11,588,420.43$ & $20,067,839$ \\
CAGR & 16.36 & 13.28 \\
\hline
\end{tabular}

Source: NAFSCOB [16].

Loan taken has increased by $14.30 \%$. The compound annual growth rate of the ten-year short term loans is equal to $13.28 \%$, representing the smooth annualized gain earned over the investment time horizon, assuming the investment was compounding over the ten-year time period. CAGR of borrowers has increased by $3.23 \%$ but total amount of loan taken and total amount of deposits have increased by $13 \%$ and $16 \%$ respectively. This means that people are willing to take greater risk for taking higher loan. The disposal income of people has increased, hence it is more appealing for the existing members to carry out transaction with 


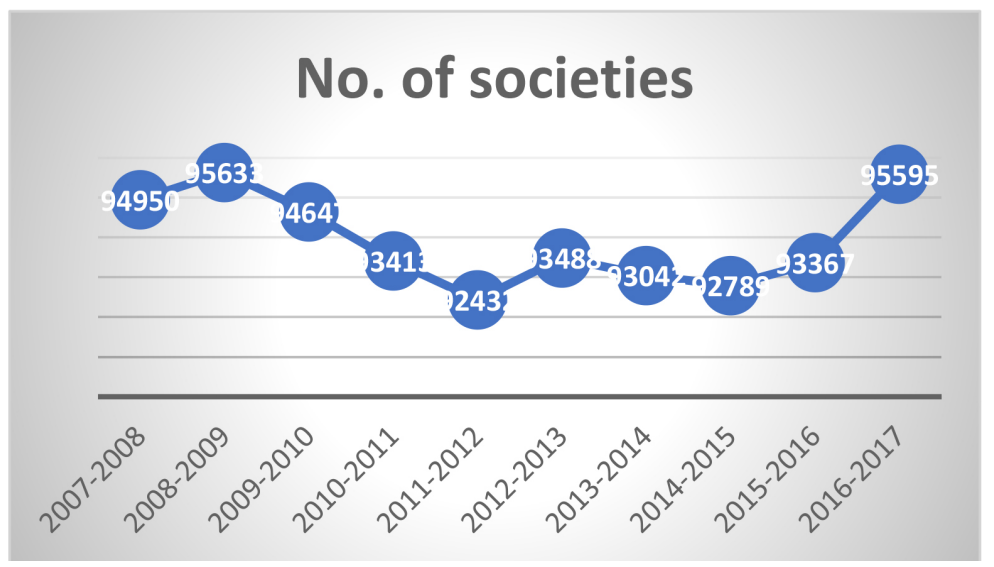

Figure 1. No. of societies.

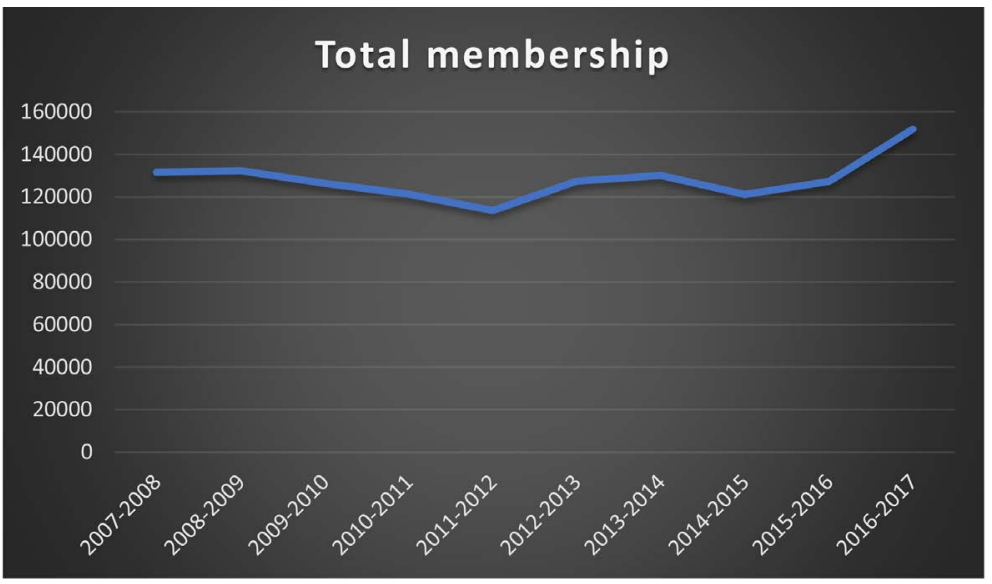

Figure 2. Total membership.

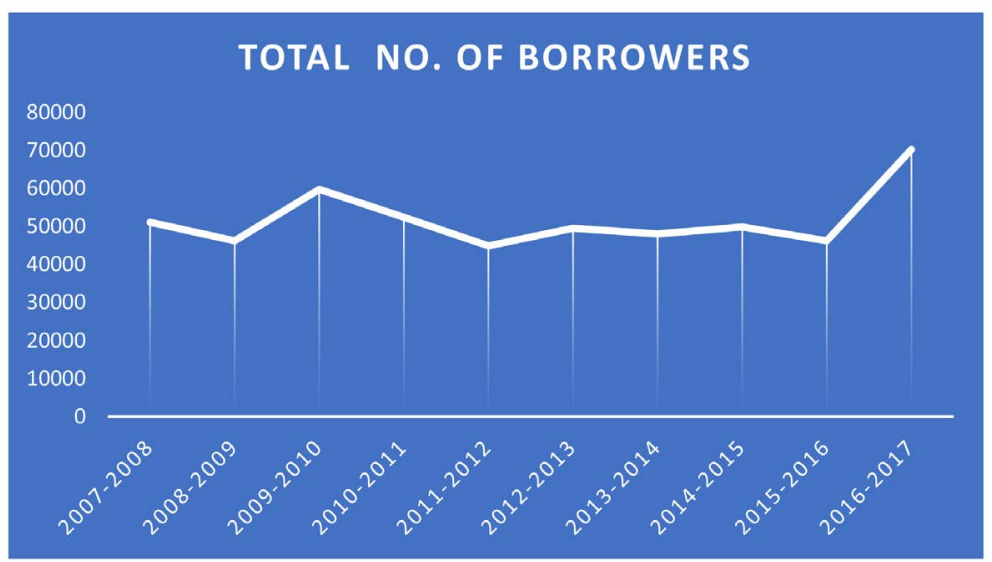

Figure 3. Total No. of Borrowers.

PACS like taking loan, and depositing money. The CAGR of total members shows a minimal increase of $1.44 \%$ but the total amount of deposits has increased by $16 \%$ thus indicating the faith people have in PAC.

In Figure 4 short term Loan advanced has been significantly increasing throughout the period of 10 years. 


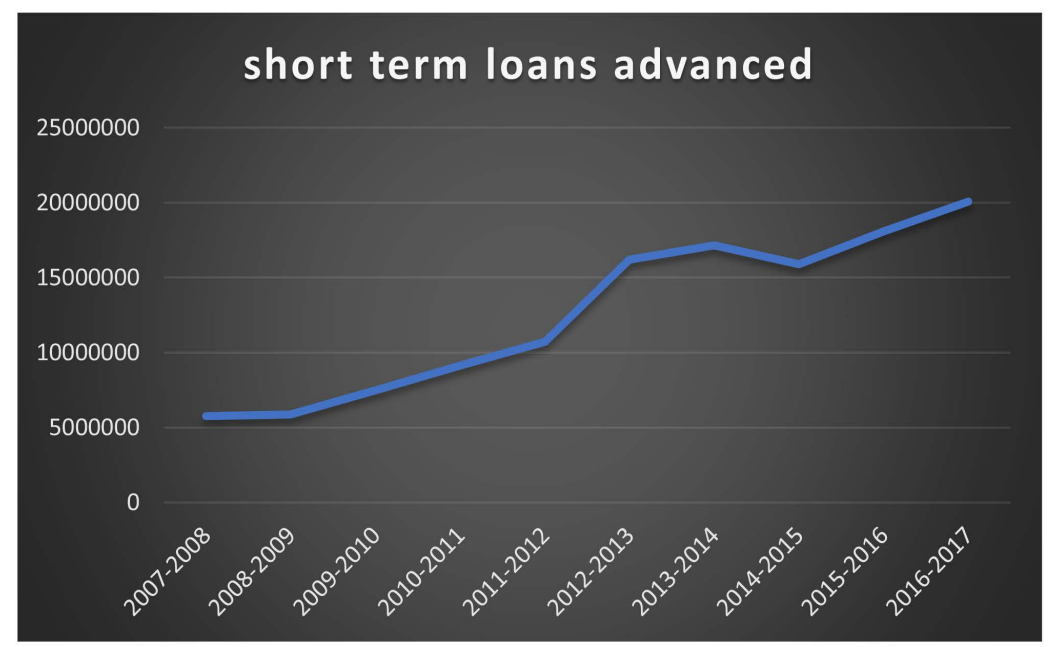

Figure 4. Short term loans advanced.

In Figure 5 the total deposits show a phenomenal increase of $350 \%$ over the span of 10 years.

\subsection{Section B: A Study on the Recommendations Made by Different Committees over the Years}

Although PACS has widened their scope in terms of memberships, deposits and loans advanced, yet it suffers from many operational and managerial shortcomings. PACS is increasingly facing competition from other financial institutions like scheduled commercial banks, regional rural banks etc. hence the Government of India and the Reserve Bank of India have set up various committees to review and restructure the non performing PACS (Senapati S. [17]). Some of the important committee recommendations are as follows.

\subsubsection{Capoor Committee (2000)}

In its report examined the various causes of continued weakness in the cooperative sector and suggested appropriate measures to revitalize and revamp the cooperatives in India. According to this report the vital link in the short term cooperative credit system are PACS at the grass root level which had generally been weak. They suffer from small size, infrastructural weakness, operational inefficiency and structural flaws. Other major factors responsible for the deterioration in the performance of cooperative credit institutions are low volume of business/low resource base, low incidence of overdues and almost stagnated recovery performance. Moreover, PACS is unable to function as member-driven organizations due to the lack of democratic management in the letter and spirit. Hence, the committee under the chairmanship of Jagdish Capoor suggested increasing the borrowing membership and volume of business to improve the performance of cooperatives. The committee also emphasized the development of local leadership which would evince keen interest in the affairs of the cooperatives leading ultimately to democratization of cooperative institutions. 


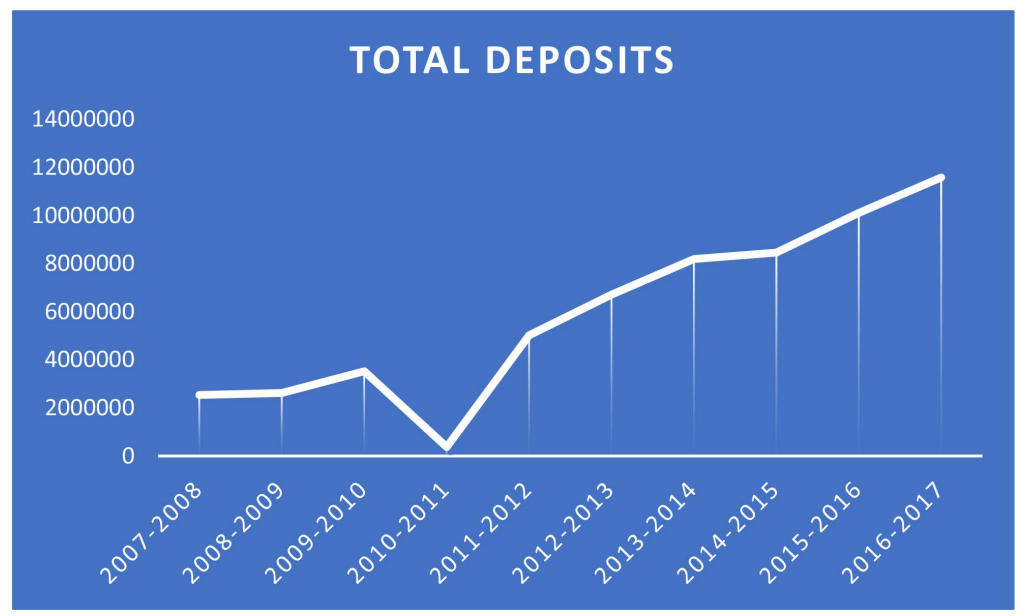

Figure 5. Total deposits.

\subsubsection{Vyas Committee Report (2004)}

This committee examined the performance of cooperatives and commercial banks in the sphere of rural credit. The cooperatives faced the problems of high rate of interest to the ultimate borrowers due to their high cost funds. Cooperatives normally offer a slightly high rate of interest of their deposits as compared to commercial banks to attract depositors. Cooperatives also apprehend paucity of funds in the near future as the depositors are shifting to other saving channels like post offices, saving deposits in commercial banks. Their scale economies are also limited. Moreover, PACS is experiencing inadequate access to credit or delayed access to DCCBs in the numbers of weak DCCBs. Hence, all these factors affect the functioning of PACS at grass root level.

\subsubsection{Vaidyanathan Committee Report (2005)}

The task force on revival of rural cooperative credit institutions was constituted by Government of India in 2004 under the chairmanship of Dr. A. Vaidyanathan to revive and rejuvenate the existing rural cooperative credit structure. According to this committee although the volume of credit flowing through cooperative credit institutions have increased, yet the performance of these institutions in terms of its share in the total institutional credit and indicators of their financial health has been less than satisfactory. The rural credit cooperatives are in an impaired state. The committee made an attempt to find out the causes of impairment in cooperative credit institutions in terms of governance, management and financial strength. The governance of PACS is affected due to the increased control and interference of the Government in the administrative matters. Audits are not done in a regular basis. Moreover, the external regulation and supervision for the structure is not as stringent as it is for commercial banking structure. The impairment in management is due to flaws in the governance of PACS. Generally the PACS has an aging staff profile characterized by inadequate professional qualification, low level of training. Financially most of the PACS is not economically viable and are running in losses. The recovery performance is very 
poor and the cost of funds is also very high. Hence, it came out with a detailed recommendation for recapitalizing the credit system with the help of cooperatives and government.

\subsubsection{High Power Committee on Cooperatives (2009)}

In order to revamp and revitalize the cooperative system, a high power committee was constituted in 2005. It was headed by Shivajirao G. Patel. The committee was of the opinion that the vast network of cooperatives in India have not received due importance despite the emphasis laid by the Planning Commission and Prime Minister Jawaharlal Nehru. It was felt that there is a need for higher authority to ensure that State Cooperative Societies Act follow the model cooperative Act both in letter and spirit. In order to enhance member participation in cooperatives and to do away with the non-user members, the Act must provide a definition of "Active member". The active member would have the right to vote and contest. It should also make provision for speedy exit of non-user member. It was also of view that the constitution should be amended to give more autonomy to cooperatives. It suggested that the utility of various tiers of the cooperative structure be examined and actions should be taken to delayer the structure in case it is not found to be cost effective.

\subsubsection{Expert Committee [18]}

The Reserve Bank constituted an Expert Committee to examine the 3-Tier Short-term Co-operative Credit Structure under the chairmanship of Dr. Prakash Bakshi. According to the committee PACS witnessed a sharp decline in the growth of credit in 2011-12 over 2010-11. The borrower-to-member ratio during 2008-09 to 2011-12 was around 40 per cent indicating that only less than half the PACS members accessed credit from these institutions. Although the percentage of loss-making PACS, has declined in recent years but it continues to be large in this sector. At end-March 2012, the percentage of loss-making PACS stood at about 39.4 per cent. To ensure safety of deposits and provide efficient loan services to farmers, the Committee has recommended that PACS should work only as business correspondents (BCs) on behalf of banks and should not themselves act as financial intermediaries. Moreover, PACS should provide a range of other fee based financial and non-financial products.

\section{Conclusion}

The study shows that number of PACS, number of members, deposits and borrowing, number of borrowers and loan issued by the primary agriculture co-operative societies in India have increased significantly during the period from 2007-2008 to 2016-2017. It indicates that the primary agriculture cooperative societies play a major role for financial empowerment of farmers and agricultural development in India. The PACS is supposed to function as viable units responsive to the needs, aspirations and convenience of its members, particularly, the members of the more vulnerable sections of the society. They are ex- 
pected to function effectively as well as efficiently managed multipurpose societies providing a package of services including credit, supply of agricultural inputs and implements, consumer goods, marketing services and technical guidance to the rural people besides mobilizing their savings as deposits. To meet the above objectives, it is essential to make the credit cooperatives more vibrant through sustained efforts. However, there appears to be no panacea for the ailment which has severely hampered their growth. Revitalization could be a plausible solution but not the only remedy. It should be supported by HRD interventions. Proper monitoring and evaluation of the working of the PACS is essential to ensure efficient functioning of PACS. The recommendations suggested by various committees have been implemented over the years which have strengthened the functioning of PACS in the cooperative credit system. However the present study has not taken into account the spatial differences in the distribution of cooperative credit system across India. Hence this can be a scope for further study by other research scholars in the future.

\section{Conflicts of Interest}

The authors declare no conflicts of interest regarding the publication of this paper.

\section{References}

[1] Belshaw, H. (1931) The Provision of Credit with Special Reference to Agriculture. Auckland University Press, Cambridge.

[2] Galbraith, J.K. (1952) The Role of Agricultural Credit in Agricultural Development. In: Proceedings of the International Conference on Agricultural and Cooperative Credit, University of California, Berkeley, CA.

[3] Schultz, T.W. (1964) Transforming Traditional Agriculture. Yale University Press, New Haven, CT.

[4] Gadgil, M.V. (1994) Formal Agricultural Credit System in India: Shape of Things to Come. Indian Journal of Agricultural Economics, 49, 470-490.

[5] Prasad, A. (2006) Recovery Performance and Overdues of Selected PACS in West Godavari District of Andhra Pradesh. Indian Cooperative Review, 43.

[6] (1989) Reserve Bank of India Bulletin. 103-196.

[7] Khusro, A.M., Reserve Bank of India (1989) Report of the Agricultural Credit Review Committee. 197-198.

[8] Baumen, F.J.A. (1989) Small, Short and Unsecured Informal Rural Finance in India. Oxford University Press, Oxford.

[9] Bhuyan, U. (2017) A Study on the Gross Deployment of Bank Credit to Various Sectors in the Economy. IJAR, 3, 308-312.

[10] Vijayakumar, J.J. (2016) Financial Performance of Primary Agriculture Co-Operative Credit Societies in India. International Journal of Advanced Scientific Research \& Development, 3, 59-67.

[11] Shah, D. (2016) Strategies to Resurrect Rural Credit Delivery System in India.

[12] Kumar, V., Wankhede, K.G. and Gena, H.C. (2015) Role of Cooperatives in Improving Livelihood of Farmers on Sustainable Basis. American Journal of Educa- 
tional Research, 3, 1258-1266.

[13] Kannusany, K. and Nirmala, S. (2011) Growth of PACS Windfall to Farmers. Vol. 48, The Co-Operator.

[14] Choudhuri, R.R., Shinde, P.S. and Mahod, P.V. (2007) Utilization and Repayment of Crop Loan by Members of PACS. Indian Cooperative Review, 44.

[15] Nayak, S. (2004) Cooperatives-The Vehicle of Economic Growth with Specific Reference to Odisha. Vol. 42.

[16] Statewise Basic Data of Primary Agricultural Cooperative Societies. http://nafscob.org/pacs_f.htm

[17] Sonali, S. (2015) Growth of Primary Agricultural Cooperative Societies (PACS) in Odisha in the Post Reform Period. Journal of Extension Education, XX, 60-65.

[18] RBI Sets up Expert Committee to Revise and Strengthen Monetary Policy Framework. https://rbi.org.in/scripts/BS_PressReleaseDisplay.aspx?prid=29535 